W czasach tzw. wojny z terroryzmem, obecnej zarówno we współczesnym polskim życiu społecznym (głównie w postaci lęków ksenofobicznych i będącej ich emanacją agresji), jak i w retoryce polskich elit politycznych, warto pamiętać, że również polscy bojownicy w okresie rozbiorów (a także później w czasach II Rzeczypospolitej oraz pod okupacją z okresu II wojny światowej, jak również we wczesnej fazie powstawania i umacniania się Polski Ludowej12) korzystali z tego typu metod walki wyzwoleńczej i politycznej. Dokonywali oni zamachów w formie zarówno indywidualnych egzekucji, jak i zbiorowych aktów przemocy. Skutkiem aktywności bojowników nierzadko były wydarzenia dramatyczne i brzemienne w następstwach, ponieważ powodowały i generowały napięcia społeczne, ale taki właśnie stan rzeczy był zgodny z celami przyświecającymi zamachowcom. Historię tych zdarzeń oraz ich kontekst społeczno-polityczny przypomniał w swojej książce R. Górski, który w interesujący i przystępny sposób przedstawił szereg zamachów z XIX i pierwszej połowy XX wieku, dokonanych przez polskich zamachowców w drodze do wolności.

Ernest Szum

Biała Podlaska

\title{
Anarquistas de Bialystok, Edicions Anomia/Furia Apátrida, Mayo 2009, Barcelona \& Manresa; 1-a Edición, 216 ss.
}

Tą pionierską publikacją poświęconą białostockim początkom polskiego (oraz prawdę mówiąc, rosyjskiego) ruchu anarchistycznego znane katalońskie oficyny libertarne zawstydziły niewątpliwie polskich badaczy tej problematyki, zwłaszcza białostockich. To nic, że nie jest to z pewnością pełna i rzetelna naukowo monografia tematu zasygnalizowanego w tytule. Znów daliśmy się ubiec, mimo wyraźnego w ostatnich latach ożywienia rodzimych badań nad dziejami anarchizmu na ziemiach polskich, które zaowocowało m.in. pierwszymi poważnymi studiami poświęconymi postaciom, takim jak Augustyn Wróblewski czy Józef Zieliński, opracowaniami dotyczącymi syndykalizmu lat międzywojennych, przygotowywanymi do druku wiwisekcjami pogromów na ziemiach polskich oraz pierwszymi specjalistycznymi konferencjami naukowymi.

$\mathrm{Na}$ barcelońskie wydawnictwo, o powodzeniu którego świadczy dobitnie druga edycja zapowiedziana na rok 2012, składają się elementy mocno zróżnicowane pod względem zawartości informacyjnej. Mamy tu więc, przede wszystkim spisane na gorąco w Paryżu w r. 1909 i opublikowane przez „Iwana Musila”, czyli Nikołaja Rogdajewa (zwanego „wujaszkiem Wanią” rosyjskiego anar-

12 Zob. A. Zechenter, Elektryk, który chciał zabić Gomułkę, „Dziennik Polski”, 13 lipca 2009 r. 
chizmu) w Almanaque Anarquista wspomnienia białostockie Judy Salmonowicza Grossmana (Roszczina) (1883-1934), słynnego żydowsko-ukraińskiego aktywisty związanego w interesującym nas okresie z tzw. „bezmotywnikami” (terror ekonomiczny jako gł. forma działania) spod znaku anarchokomunistycznych grup Czornoje Znamja (Czarny Sztandar). Kilka lat później Grossman stał się równie fanatycznym zwolennikiem anarchosyndykalizmu, po roku 1917 poparł machnowców, zaś po r. 1921 nawrócił się na marksizm, choć niekoniecznie w wersji bolszewickiej. Tylko fragment jego wspomnień, opublikowany w $1924 \mathrm{r}$. w nr 26-27 „Byłoje” znany był dotąd znawcom ruchu rewolucyjnego na ziemiach polskich. Uzupełnieniem są odezwy i nekrologi zaczerpnięte z wydanego w Moskwie w 1998 r. tomu Anarchisty. Dokumenty i materiały 1883-1935 obejmującego zasoby rosyjskich archiwów państwowych, a także teksty biograficzne z trudno dostępnej w Europie publikacji Maxa Nomada (Maksa Nachta), Dreamers, Dynamiters and Demagogues (New York 1964), gorącego zwolennika koncepcji Machajskiego. Całości dopełniają nieznane dotąd fotografie Białegostoku z epoki pogromów i nieliczne mapy z pewnością bardzo przydatne dla czytelnika hiszpańskiego. Dzieło, co charakterystyczne dla wielu publikacji anarchistycznych, nie ma autora czy autorów, ani nawet redaktora odpowiedzialnego za koncepcję edycji. Jest efektem kolektywnej współpracy dwóch oficyn wydawniczych.

Tom poświęcony białostockim bojowcom nieprzypadkowo otwiera całą serię wydawniczą prezentującą chlubne karty z dziejów XX-wiecznego anarchizmu. Jest hołdem złożonym żydowskim compañeros, z którego łatwo odczytać fascynację odwagą i czynami nastoletnich aktywistów, a także trochę zaskakujące przekonanie, iż bez nich, bez ich przykładu, nie byłaby do pomyślenia skuteczna samoobrona żydowskiej młodzieży w gettach Warszawy, Wilna czy Białegostoku w latach dużo cięższej próby dziejowej. Białystok widziany z katalońskiej i libertarnej perspektywy to nieomal miasto bliźniacze Barcelony, dumnie broniące swej odrębności. Miasto, nieomal mityczne, rozsławione przede wszystkim rewolucyjną aktywnością jego mieszkańców w latach 1905-1907.

$\mathrm{Z}$ naukowego i edytorskiego punktu widzenia recenzowana pozycja pozostawia naturalnie wiele do życzenia. Jej twórcy nie zadali sobie trudu, by dotrzeć do jakichkolwiek publikacji polskich czy poświęconych Białemustokowi. Dość subiektywnej relacji Judy Grossmana nie towarzyszy odpowiedni aparat krytyczny. Nie brak tu błędów rzeczowych i ważnych pominięć. Autorzy nie roszczą sobie jednak pretensji do wyczerpania tematu i z pewnością byliby zachwyceni, gdyby w ślad za ich „odkryciami” pojawiły się pogłębione ujęcia opisywanych w książce treści.

Wypada zatem żywić nadzieję, że tematyka białostockiego anarchizmu, bądź szerzej, białostockiego radykalizmu (wszak od lat osiemdziesiątych XIX wieku krzyżowały się tu wczesne szlaki wielu ideologii radykalnych) prędzej czy później, mimo znacznych trudności badawczych związanych z różnorodnością kultur 
i języków, wywalczy sobie należne miejsce w publikacjach młodego pokolenia historyków polskich.

Daniel Grinberg

Białystok

\section{G. Franquinet, P. Hammer, H. Schoenawa, L. Schoenawa, Litzmannstadt, Rozdzial historii niemieckiego pieniadza. Ein kapitel deutscher geldgeschichte. A Chapter of German Mo- netary History, [Regenstauf] 2010, il. cz-b., ss. 164.}

Czterech autorów (jeden Holender i trzech Niemców) wydało książkę ważną i potrzebną do poznania dziejów pieniądza zaliczanego do problematyki niemieckiej oraz polskiej numizmatyki. Z inicjatywy Holendra Guy M. Y. Ph. Franquineta $^{1}$ (urodzonego w 1947 r. w Den Haag) kupca i rzeczoznawcy numizmatycznego oraz tłumacza, zasłużone wydawnictwo „Dietl Verlag” wydało w serii „Münzen \& Sammeln” pracę poświęconą dziejom pieniądza obiegającego na rynku zamkniętym, czyli terenie getta w Lodzi.

Do współpracy zaprosił trzech wybitnych badaczy numizmatyki czasów najnowszych inż. Petera Hammera oraz Hartmuta i Lothara Schoenawa (syna i ojca). Hammer $^{2}$ (ur. $1934 \mathrm{w}$ Lipsku) to specjalista od metalu, co było niezmiernie potrzebne do analizy materiału numizmatycznego (m.in. magnezu użytego do produkcji monet), a także stempli i urządzeń do produkcji w gettcie. Rodzina zaś Schoenawa $^{3}$ (Lothar ur. w 1920 r. w Berlinie; Hartmut ur. w 1951 r. także w stolicy Niemiec) to znana i zasłużona, działająca od wielu dziesięcioleci rodzinna firma zajmująca się handlem monetami oraz wydawaniem prac i katalogów z zakresu numizmatyki - szczególnie niemieckiej.

Wydana w trzech językach (po polsku, niemiecku i angielsku) w jednym tomie jest ważnym wydarzeniem edytorskim. W jednym tomie pomieszczono bowiem dostępną wiedzę na temat pieniądza obiegającego na terenie getta łódzkiego w czasie wojny. Już samo wprowadzenie owego pieniądza jest ewene-

\footnotetext{
1 Guy Franquinet kieruje też własną firmą Dutchman Numismatik i Mineraloelgesellschaft. Poza zainteresowaniami ze sfery numizmatyki w kręgu jego zainteresowań badawczych jest także historia ruchów młodzieżowych i ruchów społecznych. Mieszka w Niemczech.

2 Peter Hammer ma tytuł dr. inż. metalurgii; od 1990 r. pracował w Niemieckim Instytucie Archeologicznym we Frankfurcie nad Menem i jest wykładowcą na wielu uczelniach niemieckich.

3 Lothar Schoenawa wraz z synem Hartmutem od 1986 r. prowadzili w Berlinie, wspólnie firmę zajmującą się handlem numizmatycznym oraz wydawnictwami. Syn był absolwentem Uniwersytetu Chemicznego i Technicznego w Berlinie. Byli specjalistami od rozpoznawania fałszerstw monet. Ojciec Lothar zmarł 7 lutego 2007 r.
} 